KEEPING IT HALAL 



\section{Keeping It Halal}

The Everyday Lives

of Muslim American

Teenage Boys

John O'Brien

PRINCETON UNIVERSITY PRESS

PRINCETON AND OXFORD 
Copyright $\odot 2017$ by Princeton University Press

Published by Princeton University Press,

41 William Street, Princeton, New Jersey 08540

In the United Kingdom: Princeton University Press,

6 Oxford Street, Woodstock, Oxfordshire OX20 ITR

press.princeton.edu

Jacket illustration, lettering, and design by Amanda Weiss

All Rights Reserved

Library of Congress Cataloging-in-Publication Data

Names: O’Brien, John (John Hoffman), 1973- author.

Title: Keeping it Halal : the everyday lives of Muslim American teenage boys / John O’Brien.

Description: Princeton : Princeton University Press, [2017] | Includes bibliographical references and index.

Identifiers: LCCN 2016058249 | ISBN 9780691168821 (hardcover : alk. paper)

Subjects: LCSH: Muslim youth-United States-Social conditions. | Muslim men-United States-Social conditions. | Muslims-Cultural assimilation-United States. | United States-Race relations.

Classification: LCC E184.M88 O27 2017 | DDC 305.6/97073-dc23

LC record available at https://lccn.loc.gov/2016058249

British Library Cataloging-in-Publication Data is available

This book has been composed in Adobe Text Pro

Printed on acid-free paper. $\infty$

Printed in the United States of America

10987765543221 
For Hamza, Nailah, and Shazia. Your Dad loves you. For Ed O'Brien (1945-2015). I love you, Dad. 
